\title{
Research and Development on Series of LNG Plate-fin Heat Exchanger
}

\author{
Zhouwei Zhang ${ }^{1,3, a}$, Yahong Wang ${ }^{2,3, b}$, Yue $\mathrm{Li}^{1, \mathrm{c}}$ and Jiaxing Xue ${ }^{1, \mathrm{~d}}$
}

${ }^{1}$ School of Environment and Municipal Engineering, Lanzhou Jiaotong University, Lanzhou 730070, China

${ }^{2}$ School of Mechanical and Electrical Engineering, Lanzhou Jiaotong University, Lanzhou 730070, China

${ }^{3}$ Gansu Zhongyuan Energy and Power Engineering Co.,Ltd.,Lanzhou 730070, China

azhangzwemail@126.com, b0701wangyahong@163.com, ${ }^{\mathrm{c}} 287794330 @ q q . c o m$, d316221260@qq.com

Keywords: Plate-fin heat exchanger; LNG; Mixed refrigerant; Plate bundle

Abstract: The research and development situations of LNG plate-fin heat exchanger (LPFHE) were discussed in view of heat exchange in LNG field in petrol-chemical industry. The basic designing methods and the multi-stream heat exchange processes were illustrated by the cryogenic and high pressure cross heat exchange equipments of LPFHE with multi-stream and multiphase flow, including Five-stream LPFHE in first stage, Four-stream LPFHE in second stage, Three-stream LPFHE in third stage, Multi-stream main LPFHE etc. A series of LPFHE with different mixed refrigerants and different applications were described. The plate arranging structure characteristics and the working principles of the plate bundles were elaborated to give references for the scientific design and calculation of LPFHE in cryogenic field. The major research directions and the critical scientific problems were forecasted.

\section{Introduction}

LNG plate-fin heat exchanger (LPFHE) is mainly used in natural gas liquefaction field, including Five-stream LPFHE in first stage [1], Four-stream LPFHE in second stage [2], Three-stream LPFHE in third stage [3], Multi-stream main LPFHE [4] etc., with phase-changed refrigeration and multi-stream of cryogenic and high pressure heat exchanger due to different liquefaction process and shape design. LPFHE mainly involves multi-stream heat exchange of mixed refrigerant in LNG cryogenic liquefaction and throttling refrigeration technology with mixed refrigerant, i.e., $\mathrm{N}_{2}, \mathrm{CH}_{4}$, $\mathrm{C}_{2} \mathrm{H}_{4}, \mathrm{C}_{3} \mathrm{H}_{8}, \mathrm{C}_{4} \mathrm{H}_{10}$ and $\mathrm{I}_{-} \mathrm{C}_{4} \mathrm{H}_{10}$ in the LPFHE, which make $36{ }^{\circ} \mathrm{C}$ and $6.1 \mathrm{MPa}$ natural gas gradually cooled to $-164{ }^{\circ} \mathrm{C}$ and liquefied and super-cooled by the multi-stage refrigeration. The LNG liquefaction process of LPFHE mainly includes three stages with mixed refrigerant. The compressed natural gas is pre-cooled from $36{ }^{\circ} \mathrm{C}$ to $-53{ }^{\circ} \mathrm{C}$ in the first stage, from $-53{ }^{\circ} \mathrm{C}$ to $-120{ }^{\circ} \mathrm{C}$ in the second stage for liquefaction preparation, $-120{ }^{\circ} \mathrm{C}$ to $-164{ }^{\circ} \mathrm{C}$ in third stage for entirely liquefaction. Three processes can use different cooling process, different refrigerant and heat exchange equipment. In order to reduce the number of heat exchangers in LNG liquefaction system, reduce the cryogenic insulation area, be convenient for maintenance and heat exchange, the three sections of the main heat exchangers can be connected together as a whole LNG liquefaction unit. Prolong heat exchanger height to $20 \sim 30 \mathrm{~m}$, the natural gas can be directly liquefied from $36{ }^{\circ} \mathrm{C}$ to $-164{ }^{\circ} \mathrm{C}$ and super-cooled through a complete LPFHE, heat exchange efficiency can be obviously improved, and management process can be more convenient.

According to the LNG liquefaction features about mixed refrigerant, apply sectioned refrigeration method with different refrigerant, in view of $\mathrm{N}_{2}, \mathrm{CH}_{4}, \mathrm{C}_{2} \mathrm{H}_{4}, \mathrm{C}_{3} \mathrm{H}_{8}, \mathrm{C}_{4} \mathrm{H}_{10}, \mathrm{I}_{-} \mathrm{C}_{4} \mathrm{H}_{10}$ refrigeration technology, LPFHE was researched and developed in the range of $36{ }^{\circ} \mathrm{C} \sim-53{ }^{\circ} \mathrm{C},-53{ }^{\circ} \mathrm{C} \sim-120{ }^{\circ} \mathrm{C}$, $-120{ }^{\circ} \mathrm{C} \sim-164{ }^{\circ} \mathrm{C}$ to solve the difficult problem of $\mathrm{LNG}$ cryogenic liquefaction process with multi-stream heat exchange and mixed refrigerant refrigeration technology. LPFHE involves cryogenic heat exchange of mixed refrigerant with multi-phase, multi-stream, back-heating and multi-stream throttling refrigeration of mixed refrigerant. It is one of the most complicated and difficult heat 
exchanger in designing, calculating and manufacturing. It is also has no universal design method, no unified calculation method, no standards, and need to re-calculate refrigerating capacity and ascertain the refrigerant mixture ratio before designing. With the greater difference of process characteristics or physical parameters, there has the greater structural difference and it is difficult to be standardized. In addition, for the more plate arranging methods of multi-stream plate bundles, there has no unified plate arranging type, theoretical designing model and calculating method for computer aided calculation, and it brings the obstacle to scientific calculation of LPFHE heat exchange.

Since 1980's in last century, APCI and Linde developed LPFHE and used it in LNG plant to solve the problem of multi-stream cryogenic heat exchange in high pressure back-refrigeration process with the higher efficiency and intensity. The natural gas can be liquefied in LPFHE directly. In China, the heat transfer mechanism [5] of multi-tream and multi-phase flow in LPFHE is researched deeply by LI Yanzhong team in Xi'an Jiaotong University since 1980s, and many papers published at home and abroad [6]. Based on its achievement, the multi-stream heat exchangers was researched systematically by Lanzhou Jiaotong University and Gansu Zhongyuan Energy and Power Engineering Co., Ltd., such as $-163{ }^{\circ} \mathrm{C}$ LPFHE used in LNG plant $[1 \sim 4],-163{ }^{\circ} \mathrm{C}$ multi-stream coil wound heat exchanger used in LNG plant $[7 \sim 10],-63{ }^{\circ} \mathrm{C}$ multi-stream heat exchanger used in rectisol plant $[11 \sim 13]$ and $-197{ }^{\circ} \mathrm{C}$ multi-stream heat exchanger used in liquid nitrogen washing plant [14 15]. According to the different temperatures and application fields, the different calculation methods were studied [16 17] for different working conditions, and the design criteria has been creating for multi-stream heat exchanger. Aiming at $-164^{\circ} \mathrm{C}$ multi-stream heat transfer characteristics and structure features of series of LPFHE, based on the development of LPFHE with Five-stream LPFHE in first stage, Four-stream LPFHE in second stage, Three-stream LPFHE in third stage, Multi-stream main LPFHE and other multi-stream, multi-phase and cryogenic heat exchanger were researched and currently the industrial designing and manufacturing capability was greatly developed.

\section{Five-stream LPFHE in first stage}

\section{Structure design and heat transfer process}

The five-stream LPFHE in first stage (Fig.1a) is mainly comprised of 37 components, such as the plates, the folded plates and the comprised channels etc., of which four channels share for the refrigerants and one for natural gas. It mainly uses the mixed refrigerant of $\mathrm{N}_{2}, \mathrm{CH}_{4}, \mathrm{C}_{2} \mathrm{H}_{4}, \mathrm{C}_{3} \mathrm{H}_{8}, \mathrm{C}_{4} \mathrm{H}_{10}$ and $\mathrm{I}_{-} \mathrm{C}_{4} \mathrm{H}_{10}$ pre-cooling the mixed refrigerant of $\mathrm{N}_{2}-\mathrm{CH}_{4}-\mathrm{C}_{2} \mathrm{H}_{4}$ and natural gas to $-53{ }^{\circ} \mathrm{C}$. The mixed refrigerant of $\mathrm{C}_{4} \mathrm{H}_{10}-\mathrm{I}_{-} \mathrm{C}_{4} \mathrm{H}_{10}$ of $36{ }^{\circ} \mathrm{C}$ and $0.9 \mathrm{MPa}$ is cooled to $-53{ }^{\circ} \mathrm{C}$ and $0.6 \mathrm{MPa}$ by the cold-side throttled $\mathrm{C}_{3} \mathrm{H}_{8}$, throttled $\mathrm{C}_{4} \mathrm{H}_{10}-\mathrm{I}-\mathrm{C}_{4} \mathrm{H}_{10}$ and $-63{ }^{\circ} \mathrm{C}$ and $0.3 \mathrm{MPa} \mathrm{N}_{2}-\mathrm{CH}_{4}-\mathrm{C}_{2} \mathrm{H}_{4}$. Then $\mathrm{C}_{4} \mathrm{H}_{10}-\mathrm{I}_{-} \mathrm{C}_{4} \mathrm{H}_{10}$ is throttled and super-cooled to $-52.85^{\circ} \mathrm{C}$ and $0.3 \mathrm{MPa}$, and flows into cold-side channels and mixed with $\mathrm{C}_{3} \mathrm{H}_{8}, \mathrm{~N}_{2}-\mathrm{CH}_{4}-\mathrm{C}_{2} \mathrm{H}_{4}$, and cools the hot-side nature gas, $\mathrm{N}_{2}-\mathrm{CH}_{4}-\mathrm{C}_{2} \mathrm{H}_{4}, \mathrm{C}_{3} \mathrm{H}_{8}$ and $\mathrm{C}_{4} \mathrm{H}_{10}-\mathrm{I}_{-} \mathrm{C}_{4} \mathrm{H}_{10}$, and finally gets out of five-stream LPFHE at $26{ }^{\circ} \mathrm{C}$ and $0.3 \mathrm{MPa}$. The hot-side refrigerant of $\mathrm{C}_{3} \mathrm{H}_{8}$ of $36{ }^{\circ} \mathrm{C}$ and $2.18 \mathrm{MPa}$ is cooled to $-53{ }^{\circ} \mathrm{C}$ and $1.88 \mathrm{MPa}$ by the cold-side mixed refrigerant of $\mathrm{N}_{2}, \mathrm{CH}_{4}, \mathrm{C}_{2} \mathrm{H}_{4}$, $\mathrm{C}_{3} \mathrm{H}_{8}, \mathrm{C}_{4} \mathrm{H}_{10}, \mathrm{I}-\mathrm{C}_{4} \mathrm{H}_{10}$, then throttled to cold-side and super-cooled to $-52.29{ }^{\circ} \mathrm{C}$ and $0.3 \mathrm{MPa}$, then mixed with the cold-side mixed refrigerant and returns to the compressor with other mixed refrigerant.

\section{Fundamental theory}

Firstly, the cryogenic heat transfer process and the overall structure of LPFHE in the first stage of 36 ${ }^{\circ} \mathrm{C} \sim-53{ }^{\circ} \mathrm{C}$ were researched and developed, and the refrigeration equipment in first stage was designed, which used $\mathrm{C}_{4} \mathrm{H}_{10}-\mathrm{I}-\mathrm{C}_{4} \mathrm{H}_{10}$ and $\mathrm{C}_{3} \mathrm{H}_{8}$ refrigeration technology providing cold capacity for the first stage. Secondly, using the throttling process of $\mathrm{C}_{4} \mathrm{H}_{10}-\mathrm{I}-\mathrm{C}_{4} \mathrm{H}_{10}$ mixed refrigerant, which is pre-cooled to -53 ${ }^{\circ} \mathrm{C}$ before throttling, can make the first stage refrigeration temperature lowered than its saturated temperature of $-14{ }^{\circ} \mathrm{C}$ and $26{ }^{\circ} \mathrm{C}$ respectively. Thirdly, using $\mathrm{C}_{3} \mathrm{H}_{8}$ refrigeration technology can acquire the lower evaporation temperature than $\mathrm{C}_{4} \mathrm{H}_{10}-\mathrm{I}-\mathrm{C}_{4} \mathrm{H}_{10}$, namely $\mathrm{C}_{3} \mathrm{H}_{8}$ can be throttled to $0.3 \mathrm{MPa}$ and $-52.29{ }^{\circ} \mathrm{C}$ after being pre-cooled to $-53{ }^{\circ} \mathrm{C}$. The three evaporation temperature of $-14{ }^{\circ} \mathrm{C}, 26{ }^{\circ} \mathrm{C}$ and $-52.29{ }^{\circ} \mathrm{C}$, throttled from $\mathrm{C}_{4} \mathrm{H}_{10}-\mathrm{I}_{-}-\mathrm{C}_{4} \mathrm{H}_{10}$ and $\mathrm{C}_{3} \mathrm{H}_{8}$, can be obtained and it can reduce the entropy 
increment in heat transfer process. $\mathrm{N}_{2}-\mathrm{CH}_{4}-\mathrm{C}_{2} \mathrm{H}_{4}$ was pre-cooled and mainly used in refrigeration process for the second and third stage. therefore, there were four-stream flows in hot-side in heat transfer process in first stage.

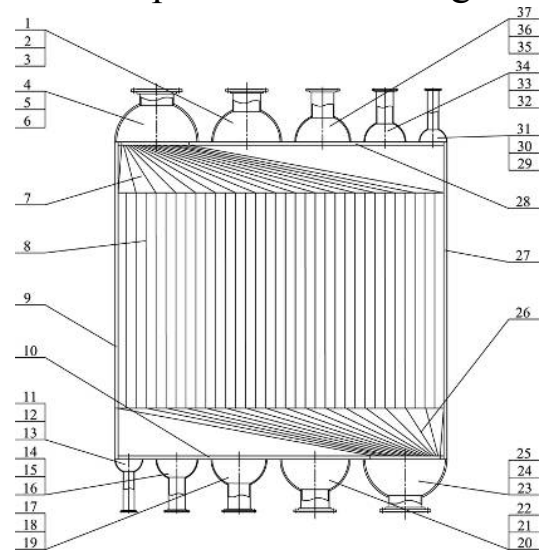

(a) Five-stream LPFHE in first stage

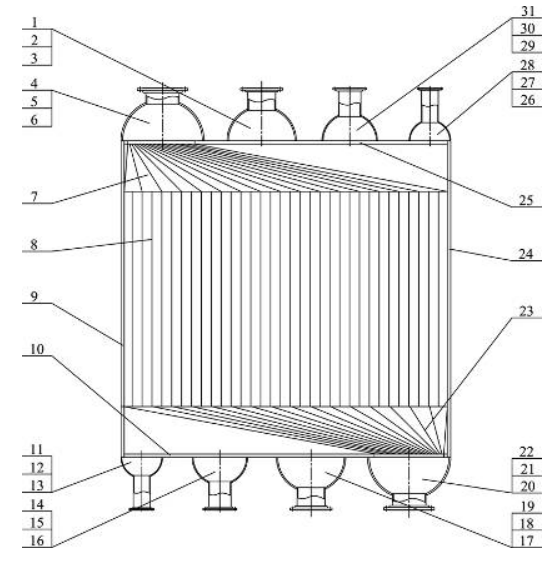

(b) Four-stream LPFHE in second stage

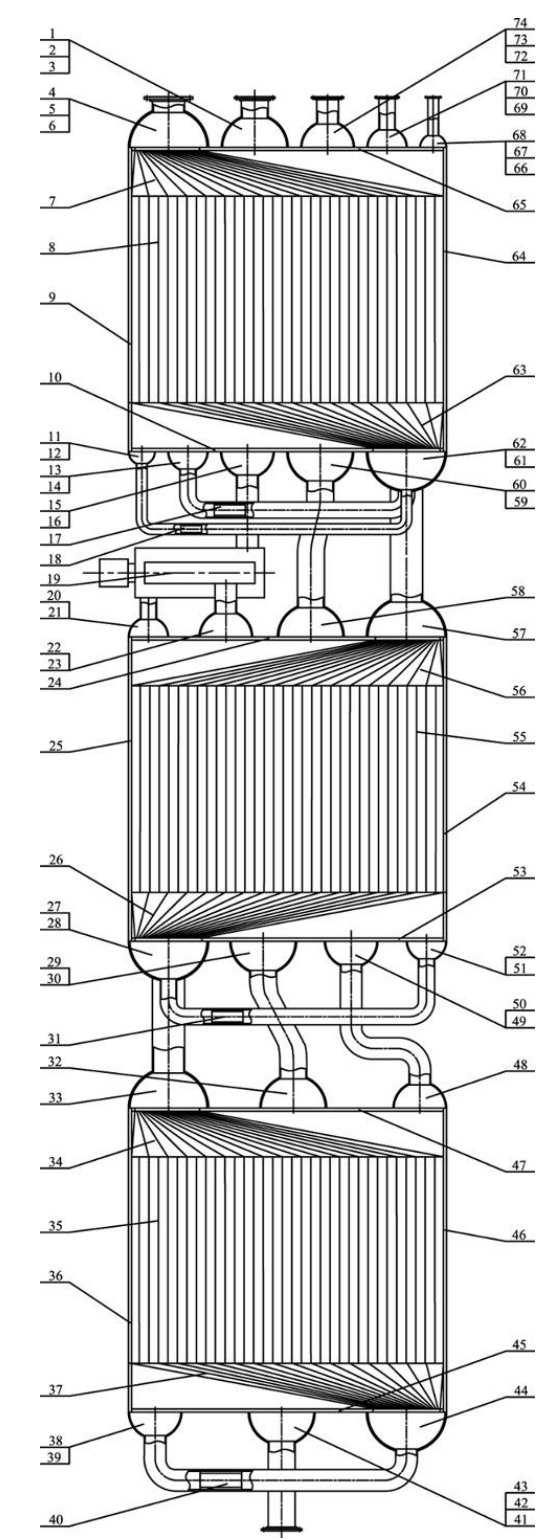

(d) Multi-stream main LPFHE

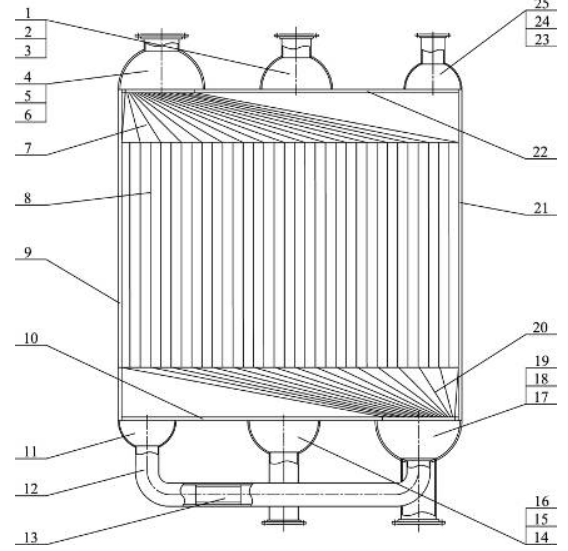

(c) Three-stream LPFHE in third stage

Fig. 1. Series of LNG plate-fin heat exchanger 


\section{Three-stream LPFHE in second stage}

\section{Structure design and heat transfer process}

The four-stream LPFHE in second stage (Fig. 1b) is mainly comprised of 31 components, such as the plates, the folded plates and the comprised channels etc., of which three channels share for the refrigerants and one for natural gas. It mainly uses the cold-side mixed refrigerant of $\mathrm{N}_{2}, \mathrm{CH}_{4}$ and $\mathrm{C}_{2} \mathrm{H}_{4}$ pre-cooling the hot-side mixed refrigerant of $\mathrm{N}_{2}-\mathrm{CH}_{4}, \mathrm{C}_{2} \mathrm{H}_{4}$ and natural gas to $-120{ }^{\circ} \mathrm{C}$. The hot-side refrigerant $\mathrm{C}_{2} \mathrm{H}_{4}$ of $-53{ }^{\circ} \mathrm{C}$ and $1.88 \mathrm{MPa}$ is cooled to $-120{ }^{\circ} \mathrm{C}$ by the throttled $\mathrm{C}_{2} \mathrm{H}_{4}$ and cold-side -130 ${ }^{\circ} \mathrm{C}$ and $0.3 \mathrm{MPa} \mathrm{N}{ }_{2}-\mathrm{CH}_{4}$. Then $\mathrm{C}_{2} \mathrm{H}_{4}$ is throttled and super-cooled to $-119.4{ }^{\circ} \mathrm{C}$ and $0.3 \mathrm{MPa}$, and gets into the cold-side and mixed with cold-side $\mathrm{N}_{2}-\mathrm{CH}_{4}$, and cools the plate bundles of nature gas, $\mathrm{N}_{2}-\mathrm{CH}_{4}$ and $\mathrm{C}_{2} \mathrm{H}_{4}$, and finally gets out of three-stream LPFHE at $-63{ }^{\circ} \mathrm{C}$ and $0.3 \mathrm{MPa}$. The hot-side $\mathrm{N}_{2}-\mathrm{CH}_{4}$ of $-53{ }^{\circ} \mathrm{C}$ and $1.8 \mathrm{MPa}$ is pre-cooled to $-120{ }^{\circ} \mathrm{C}$ by the throttled $\mathrm{C}_{2} \mathrm{H}_{4}$ and $-130{ }^{\circ} \mathrm{C}$ and $0.3 \mathrm{MPa} \mathrm{N}_{2}-\mathrm{CH}_{4}$ in cold-side, then flows into the third stage. Natural gas of $-53{ }^{\circ} \mathrm{C}$ and $5.8 \mathrm{MPa}$ is pre-cooled to $-120{ }^{\circ} \mathrm{C}$ by cold-side $\mathrm{N}_{2}-\mathrm{CH}_{4}-\mathrm{C}_{2} \mathrm{H}_{4}$, then liquefied and flows out the second stage and enters the third stage.

\section{Fundamental theory}

Firstly, the cryogenic heat transfer process and the overall structure of LPFHE in the second stage of $-53{ }^{\circ} \mathrm{C} \sim-120^{\circ} \mathrm{C}$ were researched and developed, and the refrigeration equipment in second stage was designed, which used $\mathrm{C}_{2} \mathrm{H}_{4}$ refrigeration technology provide cold capacity for the second stage. Secondly, using $\mathrm{C}_{2} \mathrm{H}_{4}$ throttling process which is pre-cooled to $-120{ }^{\circ} \mathrm{C}$ and liquefied before throttling can provide cold capacity for the second stage. The pre-cooling processes of $\mathrm{N}_{2}-\mathrm{CH}_{4}, \mathrm{C}_{2} \mathrm{H}_{4}$ and natural gas are carried out at the same time, so the four-stream heat transfer process is adopted.

\section{Two-stream LPFHE in third stage}

\section{Structure design and heat transfer process}

The three-stream LPFHE in third stage (Fig.1c) is mainly comprised of 25 components, such as the plates, the folded plates and the comprised channels etc., of which two channels share for the refrigerants and one for natural gas. It mainly uses the cold-side mixed refrigerant of $\mathrm{N}_{2}$ and $\mathrm{CH}_{4}$ pre-cooling the hot-side mixed refrigerant of $\mathrm{N}_{2}-\mathrm{CH}_{4}$ and super-cooling natural gas to $-161^{\circ} \mathrm{C}$. The $\mathrm{N}_{2}-\mathrm{CH}_{4}$ of $-120^{\circ} \mathrm{C}$ and $1.58 \mathrm{MPa}$ is cooled to $-164{ }^{\circ} \mathrm{C}$ by the cold-side $\mathrm{N}_{2}$ and $\mathrm{CH}_{4}$ and liquefied completely, then throttled to $-185{ }^{\circ} \mathrm{C}$ and $-163.5{ }^{\circ} \mathrm{C}$ in cold-side respectively. Natural gas of -120 ${ }^{\circ}$ Cand $5.5 \mathrm{MPa}$ is liquefied entirely by cold-side $\mathrm{N}_{2}$ and $\mathrm{CH}_{4}$ to $-164^{\circ} \mathrm{C}$ and $5.3 \mathrm{MPa}$, then depressurized to $0.1 \mathrm{MPa}$ by the throttle valve and finally flows into the LNG storage tank.

\section{Fundamental theory}

Firstly, the cryogenic heat transfer process and the overall structure of LPFHE in the third stage of $-120^{\circ} \mathrm{C} \sim-164{ }^{\circ} \mathrm{C}$ were researched and developed, and the refrigeration equipment in third stage was designed, which used $\mathrm{N}_{2}-\mathrm{CH}_{4}$ refrigeration technology to provide cold capacity for the third stage. Secondly, by using throttling technology, $\mathrm{N}_{2}-\mathrm{CH}_{4}$ can be pre-cooled to $-164^{\circ} \mathrm{C}$ and liquefied before throttling. The temperature of throttled $\mathrm{N}_{2}$ and $\mathrm{CH}_{4}$ reach $-185^{\circ} \mathrm{C}$ and $-163.5^{\circ} \mathrm{C}$ respectively, and the sufficient cold capacity can be obtained for refrigeration in third stage.

\section{Multi-stream main LPFHE}

\section{Structure design and heat transfer process}

The multi-stream main LPFHE (Fig. 1d) is mainly comprised of three sections illustrated above with 74 major components. It mainly uses the cold-side mixed refrigerant of $\mathrm{N}_{2}, \mathrm{CH}_{4}, \mathrm{C}_{2} \mathrm{H}_{4}, \mathrm{C}_{3} \mathrm{H}_{8}, \mathrm{C}_{4} \mathrm{H}_{10}$, $\mathrm{I}-\mathrm{C}_{4} \mathrm{H}_{10}$ pre-cooling the hot-side mixed refrigerant and liquefying natural gas to $\mathrm{LNG}$ in three sections, which includes three temperature intervals of $36{ }^{\circ} \mathrm{C} \sim-53{ }^{\circ} \mathrm{C},-53{ }^{\circ} \mathrm{C} \sim-120{ }^{\circ} \mathrm{C},-120{ }^{\circ} \mathrm{C} \sim-164{ }^{\circ} \mathrm{C}$. Using three interval multi-streams LPFHE, heat transfer process from high to low was fulfilled in three intervals, and heat exchanger structure and the cryogenic heat transfer process were studied and developed. 
The mixed refrigerant of $\mathrm{C}_{4} \mathrm{H}_{10}-\mathrm{I}_{-} \mathrm{C}_{4} \mathrm{H}_{10}$, which is pre-cooled from $36{ }^{\circ} \mathrm{C}$ and $0.9 \mathrm{MPa}$ to $-53{ }^{\circ} \mathrm{C}$ and $0.6 \mathrm{MPa}$, then throttled to $-52.85{ }^{\circ} \mathrm{C}$ and $0.3 \mathrm{MPa}$, provides cold capacity for the first integral. $\mathrm{C}_{3} \mathrm{H}_{8}$, which is pre-cooled from $36^{\circ} \mathrm{C}$ and $2.18 \mathrm{MPa}$ to $-53{ }^{\circ} \mathrm{C}$ and $1.88 \mathrm{MPa}$, then throttled to $-52.29{ }^{\circ} \mathrm{C}$ and $0.3 \mathrm{MPa}$, also provides cold capacity for the first interval. The mixed refrigerant of $\mathrm{N}_{2}-\mathrm{CH}_{4}-\mathrm{C}_{2} \mathrm{H}_{4}$, which is pre-cooled from $36{ }^{\circ} \mathrm{C}$ and $2.18 \mathrm{MPa}$ to $-53{ }^{\circ} \mathrm{C}$ and $1.88 \mathrm{MPa}$, then $\mathrm{C}_{2} \mathrm{H}_{4}$ is liquefied and separated, super-cooled to $-120{ }^{\circ} \mathrm{C}$ and $1.58 \mathrm{MPa}$, then throttled to $-119.4{ }^{\circ} \mathrm{C}$ and $0.3 \mathrm{MPa}$ and provides cold capacity for the second interval. $\mathrm{N}_{2}-\mathrm{CH}_{4}$ is pre-cooled in the second interval and the third interval and finally to $-164{ }^{\circ} \mathrm{C}$ and $1.38 \mathrm{MPa}$, then throttled to $0.3 \mathrm{MPa}$, and the temperature of $\mathrm{N}_{2}$ is $-185^{\circ} \mathrm{C}, \mathrm{CH}_{4}$ is $-163.5^{\circ} \mathrm{C}$, they all provide cold capacity for the third interval. Natural gas is cooled from $36{ }^{\circ} \mathrm{C}$ and $6.1 \mathrm{MPa}$ to $-164{ }^{\circ} \mathrm{C}$ and $5.3 \mathrm{MPa}$ and entirely liquefied and super-cooled after three interval refrigeration and finally stored in LNG tank.

\section{Fundamental theory}

The main LPFHE contains the three refrigeration processes, which is independent but organically combined together. It is also convenient for transport and on-site assembly. Using $\mathrm{C}_{4} \mathrm{H}_{10}-\mathrm{I}_{-} \mathrm{C}_{4} \mathrm{H}_{10}$ and $\mathrm{C}_{3} \mathrm{H}_{8}$ refrigeration processes in the first interval can pre-cool the mixed refrigerant of $\mathrm{N}_{2}-\mathrm{CH}_{4}-\mathrm{C}_{2} \mathrm{H}_{4}$ and natural gas to $-53{ }^{\circ} \mathrm{C}$. Using $\mathrm{C}_{2} \mathrm{H}_{4}$ refrigeration process in the second interval can pre-cool the mixed refrigerant of $\mathrm{N}_{2}-\mathrm{CH}_{4}$ and natural gas to $-120{ }^{\circ} \mathrm{C}$. Using $\mathrm{N}_{2}-\mathrm{CH}_{4}$ refrigeration process in the third interval can pre-cool the mixed refrigerant of $\mathrm{N}_{2}-\mathrm{CH}_{4}$ and natural gas to $-164{ }^{\circ} \mathrm{C}$. A five-stream LPFHE is adopted in the first interval, a four-stream LPFHE is adopted in the second interval and a three-stream LPFHE is adopted in the third interval. Using non-azeotropic mixed refrigerant of $\mathrm{N}_{2}$, $\mathrm{CH}_{4}, \mathrm{C}_{2} \mathrm{H}_{4}, \mathrm{C}_{3} \mathrm{H}_{8}, \mathrm{C}_{4} \mathrm{H}_{10}$ and $\mathrm{I}_{-} \mathrm{C}_{4} \mathrm{H}_{10}$ can generate enough cold capacity and different evaporation temperature from $26^{\circ} \mathrm{C}$ to $-185^{\circ} \mathrm{C}$ in order to reduce the entropy increment in three intervals in LNG liquefaction process.

\section{Conclusion}

The scientific calculation method of the mixed refrigerants involves $\mathrm{N}_{2}, \mathrm{CH}_{4}, \mathrm{C}_{2} \mathrm{H}_{4}, \mathrm{C}_{3} \mathrm{H}_{8}, \mathrm{C}_{4} \mathrm{H}_{10}$, $\mathrm{I}-\mathrm{C}_{4} \mathrm{H}_{10}$ multi-phase, multi-stream flow and cryogenic heat transfer in LNG liquefaction process. The accurate calculation of a number of heat transfer films, heat transfer coefficient and variation regularity are still key problems for the design calculation of LPFHE and still need further research and development. Because of variation of the heat transfer coefficient with phase changed refrigeration and multi-stream heat exchange at any time, especially more than 12 streams of different fluids exchange heat with multi-phase flow in each bundle. When all of the plate bundles are combined together, the calculation method of heat transfer becomes the key scientific problem. If this problem can be solved scientifically, the overall design of the LPFHE should be more scientific and effective.

The scientific balance algorithm of LPFHE is still a key problem needed for further study. According to the traditional calculation of total heat transfer coefficient, the multiple iterative calculations are required in refrigeration process. In order to make the total heat exchange balancing to the number of channels, the design process of LPFHE involves many iterative computation methods for multi-stream, multi-phase and cryogenic fluid, and the calculation software is needed for heat exchange equilibrium, which provide theoretical and calculating method for LPFHE.

\section{Acknowledgements}

This project was financially supported by The fundamental research funds of department of finance in Gansu province (214137), The Gansu Natural Science Foundation (1208RJZA234), The master tutor project of Gansu Province (1104-01). Thanks for National Key Lab. of Vacuum \& Cryogenics Technology and Physics in China. 


\section{References}

[1] Zhang Zhou-wei. A cryogenic plate-fin heat exchanger with five-stream in the first stage of LNG liquefaction process[P].China: 201510040244.7, 2012.05.

[2] Zhang Zhou-wei. A cryogenic plate-fin heat exchanger with four-stream in second stage of LNG liquefaction process[P]. China:201510042630.X, 2012.08.

[3] Zhang Zhou-wei. A cryogenic plate-fin heat exchanger with three-stream in third stage of LNG liquefaction process[P]. China:201510040244.7, 2012.08.

[4] Zhang Zhou-wei. A main cryogenic plate-fin heat exchanger with multi-stream mixed-refrigerant in the LNG liquefaction process [P]: China,201510051091.6, 2012.08.

[5] Wang Sun-han etc., Plate-fin heat exchanger[M].Beijing:Chemical Industry Press, 1984.

[6] Min Zhao, Yanzhong Li. An effective layer pattern optimization model for multi-stream plate-fin heat exchanger using genetic algorithm[J]. International Journal of Heat and Mass Transfer 60 (2013) 480-489.

[7] Zhang Zhou-wei. A cryogenic spiral coil-wound heat exchanger with four stream in the first stage of LNG liquefaction process[P].China:201110379518.7, 2012.05.

[8] Zhang Zhou-wei. A cryogenic spiral coil-wound heat exchanger with three stream in second stage of LNG liquefaction process[P]. China:201110376419.3, 2012.08.

[9] Zhang Zhou-wei. A main cryogenic spiral coil-wound heat exchanger with multi-stream mixed-refrigerant in the LNG liquefaction process[P]: China, 201110381579.7, 2012.08.

[10] Zhang Zhou-wei, Wang Ya-hong. coil-wound heat exchanger [M].Lanzhou:Lanzhou University Press, 2014.6.

[11] Zhang Zhou-wei. The cryogenic spiral coil-wound heat exchanger for unshifted feed gas cooler, [P].China: 201210569754.X, 2013.04.

[12] Zhang Zhou-wei. The cryogenic spiral coil-wound heat exchanger for shifted feed gas cooler [P].China: 201310000047.3, 2013.04.

[13] Zhang Zhou-wei. The three-stream cryogenic spiral coil-wound heat exchanger for feed gas cooler [P].China: 201310034723.9, 2013.05.

[14] Zhang Zhou-wei. The main multi-stream coil-wound heat exchanger for the heat recovery of cryogenic liquid nitrogen[P].China: 201310366573.1, 2013.08.

[15] Zhang Zhou-wei. The third-stage spiral coil-wound heat exchanger for the heat recovery of cryogenic liquid nitrogen[P].China:201310358118.7, 2013.08.

[16] Zhang Zhou-wei, Xue Jia-xing, Wang Ya-hong. Calculation and design method study of the coil-wound heat exchanger [J]. Advanced Materials Research, 2014, Vols. 1008-1009: 850-860.

[17] Zhang Zhou-wei, Li Lian-bo, Li Jun. The design and caculation software for coil-wound heat exchanger [Z]. Chinese Copyright Protection Center, 201310358118.7, 2011.09. 